\title{
Pengaruh Kondisi Sosial Ekonomi terhadap Stres Guru di SMA Negeri 1 Kampar Kiri Hilir
}

\author{
MUSADDAD HARAHAP* \\ ARY ANTONY PUTRA** \\ *Fakultas Agama Islam (FAI) Universitas Islam Riau (UIR) Pekanbaru, \\ Jl. Kaharuddin Nasution, No. 113, Perhentian Marpoyan Pekanbaru 28284 \\ E-mail: musaddadharahap@fis.uir.ac.id \\ **Fakultas Agama Islam (FAI) Universitas Islam Riau (UIR) Pekanbaru, \\ Jl. Kaharuddin Nasution, No. 113 Perhentian Marpoyan Pekanbaru 28284 \\ Telp : 081319952829 Email : aryantonyputra@fis.uir.ac.id
}

\begin{abstract}
Absrtak: Profesi guru merupakan pekerjaan yang sangat mulia karena merupakan wujud pengabdian diri untuk mengembangkan fitrah yang diberikan Allah SWT kepada manusia yaitu dengan memberikan pendidikan, pengajaran, bimbingan yang baik sehingga peserta didik menjadi insan kamil. Untuk itu guru perlu dihargai dan salah satunya dengan memberikan kesejahteraan yang layak bagi kehidupan mereka. Masalah dalam penelitian ini adalah bagaimanakah pengaruh tingkat sosial ekonomi dan stres pada guru, apakah ada pengaruh tingkat sosial ekonomi terhadap stres pada guru di dan seberapa besar pengaruh tingkat sosial ekonomi dengan stres pada guru di SMAN 1 Kampar Kiri Hilir. Metode yang digunakan adalah kuantitaf untuk mengungkap data pengaruh antara variabel tingkat sosial ekonomi dengan stres guru. Setelah dilakukan penelitian maka dapat ditemukan Tingkat sosial ekonomi guru di SMAN 1 Kampar Kiri Hilir tergolong pada tingkat menengah kebawah. Hasil penelitian ini menyatakan bahwa rxy>rt, dimana rxy pada taraf signifikan $5 \%=0,374$ dan pada taraf signifikansi $1 \%=0,478$. Jadi, rxy $>$ rt $5 \%=0,374>0,478$, karena rxy lebih besar dari rt, maka hipotesa alternative (Ha) yang menyatakan adanya korelasi atau pengaruh positif yang signifikan antara tingkat sosial ekonomi dengan stres pada guru diterima, sementara Ho ditolak, maksudnya semangkin tinggi tingkat sosial ekonomi guru, maka akan semakin rendah tingkat stres pada guru.
\end{abstract}

Kata Kuci: Kondisi Sosial Ekonomi, Stres Guru, SMA Negeri

\section{PENDAHULUAN}

Dalam Islam tidak dibenarkan memisahkan kehidupan dunia dengan akhirat, keduanya haruslah sejalan untuk mencapai kehidupan yang baik sesuai dengan apa yang digariskan oleh Allah SWT. Pada hakikatnya setiap aktivitas manusia di dunia akan berdampak pada kehidupannya kelak di akhirat. Oleh karena itu, aktivitas keduniaan tidak boleh mengorbankan kehidupan akhirat begitu pula sebaliknya aktivitas untuk akhirat (ibadah) jangan sampai kehidupan akhirat terlupakan.

Dengan bekerja manusia tidak hanya akan mendapatkan kebahagiaan dunia tetapi juga kebahagian akhirat termasuk di dalamnya kebahagiaan rohani. Banyak upaya yang dilakukan seseorang untuk memenuhi kebutuhannya tersebut dengan jenis pekerjaan yang bermacam-macam. Profesi guru merupakan salah satu jenis pekerjaan yang selain memberikan kebahagian akhirat tetapi juga kebahagiaan 
dunia. Dengan menyumbangkan ilmunya berarti guru telah melaksanakan sebagian ibadah yang akan memberinya kebahagiaan akhirat. Dan dari profesinya tersebut guru mendapatkan haknya berupa pendapatan yang akan memberikan kebahagiaan dunia.

Dengan demikian profesi guru merupakan pekerjaan yang sangat mulia karena ia telah megabdikan dirinya dalam usaha untuk mengembangkan fitrah yang diberikan Allah SWT kepada manusia yaitu dengan memberikan pendidikan, pengajaran, bimbingan yang baik sehingga diharapkan manusia atau pserta didik tersebut menjadi insan kamil. Untuk itu guru perlu dihargai dan salah satunya dengan memberikan kesejahteraan yang layak bagi kehidupan mereka. Sehingga mereka dapat menjalankan tugas dan tanggung jawab dengan sebaik-baiknya.

Kesejahteraan guru merupakan salah satu prasyarat yang harus diperhatikan jika memang harapan untuk menghasilkan pendidikan yang baik. Guru sebagai pendidik pada kenyataannya adalah manusia biasa yang membutuhkan kebutuhan-kebutuhan baik sandang dan pangan. Guru juga tentu saat-saat tertentu mengalami problem kesehatan.Semua itu tidaklah dapat diwujudkan bila guru tidak memiliki pendapatan yang memadai dari aktivitasnya sebagai guru. Kebutuhan sandang dan pangan yang terus meningkat, berbagai pengobatan baik dari dokter dan pengobatan melalui alternatif yang semakin hari semakin mahal, dan kebutuhan-kebutuhan pokok lainnya kelihatannya terus naik, semua itu tidak akan bisa terpenuhi bila perhatian terhadap kesejahteraan guru tidak benarbenar mendapat perhatian.

Selain dari pada itu, eraglobalisasi yang ditandai dengan pesatnya perkembangan ilmu pengetahuan dan teknologi serta perkembangan informasi dan komunikasi seyogianya sangat membantu guru untuk meningkatkan keprofesionalannya sebagai guru, namun bila keseimbangan kesejahteraan yang diberikan kepada mereka jauh dari ideal maka sulit untuk mengatakan bahwa peluang yang begitu baik untuk menambah pengetahuan dan wawasan mereka justru akan sia-sia belaka. Sebab, bila ingin mampu beradaptasi dengan perkembangan globalisasi seperti saat ini tentu harus memiliki produk-produknya dan juga harus memiliki kemampuan khusus. Untuk itu, bila memang diharapkan guru harus dapat meningkatkan keterampilannya sebagai pendidik dengan menggunakan IPTEK dan mampu mengkonsumsi perkembangan komunikasi dan informasi tentu mereka harus memiliki materi penunjang untuk bisa melakukan gerakangerakan mengarah ke sana. Hal ini harus menjadi perhatian serius sebab bila ditelusuri kembali UURI Nomor: 14 Tahun 2005 tentang Guru dan Dosen dijelaskan bahwa guru itu adalah profesionalisme, sementara yang dimaksud dengan profesional adalah pekerjaan atau kegiatan yang dilakukan oleh seseorang dan menjadi sumber penghasilan kehidupan yang memerlukan keahlian, kemahiran, atau kecakapan yang memenuhi standar mutu atau norma tertentu serta memerlukan pendidikan profesi. (UU Sikdiknas, 2007: 85).

Namun apa yang dikhawatirkan dalam pemberian kesejahteraan guru tampaknya masih sangat memperihatinkan. Bila ditelusuri di lapangan masih banyak didapatkan seorang guru terpaksa bekerja sampingan menjadi tukang ojek ataupun mengajar di beberapa sekolah dari pagi sampai sore hari, namun tetap saja tidak dapat meningkatkan kesejahteraan mereka. Berita tentang kurangnya kesejahteraan guru telah sering kali publikasikan, namun kenyataaannya hal itu tetap tidak membuat berbagai pihak khususnya pemerintah tergerak untuk membuat kebijakan yang benar-benar menuntaskan persoalan klasik pendidikan. Sangatlah wajar apabila organisasi internasional menilai Indonesia sebagai negara terpuruk kedua dalam perhatiannya tentang penanganan 
terhadap pendidikan rakyatnya, sangatlah jauh apabila dibandingkan dengan negaranegara tetangga di Asia seperti Malaysia, Philipina. (Suhartini, 2007: 7). Tingkat kesejahteraan guru secara nasional memang tergolong rendah, meskipun terus diupayakan perbaikan terhadap kesejahteraan guru, namun realitas menunjukan bahwa masih banyak guru yang dililit hutang dengan tergadainya SK di bank untuk menutupi banyaknya kebutuhan yang harus mereka tanggung.

Fenomena yang menghantui profesi guru saat ini, mengakibatkan guru mudah tertekan dan akhirnya stres. Pada saat seperti itu, guru dapat menderita "stres", yakni suatu keadaan dimana individu mengalami kelelahan fisik, emosional dan mental, atau juga bisa bermakna stres dan kelelahan emosional, frustasi, dan keletihan yang terjadi jika rangkaian peristiwa di suatu hubungan, misi, cara hidup, pekerjaan atau bisnis tidak menghasilkan sesuatu yang sesuai dengan harapan. (UU Sikdiknas, 2007: 85). Sedangkan menurut Pestonjee, secara teoritis stres diartikan sebagai sebuah atau beberapa rangsangan pada tekanan yang dialami yang tidak dapat diakomodasikan atau ditahan yang pada akhirnya dapat menyebabkan gangguan atau kerusakan pada kesehatan maupun tingkah laku orang tersebut.Agarwala pada tahun 1979 menyatakan bahwa secara psikologis, stres merupakan hasil dari interaksi antara seorang manusia dengan lingkungan di sekitarnya.

Dengan demikian berdasarkan beberapa pendapat tersebut dapat disimpulkan bahwa stres adalah tanggapan seseorang terhadap rangsangan atau faktor-faktor di luar dirinya yang menyebabkan terjadinya tekanan yang direaksikan dalam bentuk gangguan baik fisik maupun psikisnya. Atau dengan kata lain stres adalah suatu tekanan/ketegangan yang dialami seseorang karena adanya ketidaksesuaian antara lingkungan dengan sumberdaya yang dimilikinya, sehingga menimbulkan reaksi-reaksi terhadap kondisi tersebut.

Jadi untuk mengukur tingkat sosial ekonomi guru diperlukan suatu ukuran yang pasti. Di Indonesia terdapat standar ukuran pendapatan yang menunjukan ukuran minimum pendapatan seseorang. Berdasarkan Keputusan Gubernur Riau Nomor: kpts. 15/ I/2016. Dalam SK tersebut ditetapkan UMK Riau Rp. 2.095. 000,-.

Berdasarkan keputusan tersebut diketahui bahwa dari hasil observasi awal peneliti didapatkan data bahwa pendapatan para guru di SMA Negeri 1 Kampar Kiri Hilir Propinsi Riau sebagian besar berada di atas standar Upah Minimun Kota tersebut. Untuk lebih jelasnya dapat dilihat pada tabel di bawah ini:

\section{Tabel 1}

Tingkat Pendapatan Guru SMA Negeri 1 Kampar Kiri Hilir Berdasarkan UMK

\begin{tabular}{|c|c|c|c|}
\hline No. & $\begin{array}{l}\text { Pendapatan guru } \\
\text { Berdasarkan UMK }\end{array}$ & $\mathrm{F}$ & $\mathrm{P}(\%)$ \\
\hline \multirow{3}{*}{$\begin{array}{l}1 . \\
2 .\end{array}$} & $>$ Rp. 2. 095. 000 & 19 & 63,33 \\
\hline & $\begin{array}{l}\text { perbulan } \\
<\text { Rp. 2. 095. } 000 \\
\text { perbulan }\end{array}$ & 11 & 36,66 \\
\hline & Jumlah guru & 30 & 100 \\
\hline
\end{tabular}

Tabel di atas menunjukkan bahwa $63,33 \%$ pendapatan para guru di SMA Negeri 1 Kampar Kiri Hilir berada di atas Upah Minimum Kota (UMK). Sedangkan keadaan sosial ekonomi guru lainnya yaitu perumahan, para guru di SMA tersebut rata-rata memiliki rumah sendiri walaupun masih berstatus kredit. Yang tinggal di rumah kontrakan hanya beberapa saja, bahkan guru yang berstatus honorer dan belum menikah masih ada yang sebagian yang tinggal di rumah orangtuanya, hal ini berarti kehidupan mereka dapat dikatakan masih tetap dalam tanggungan orangtuanya, walaupun sebagian lainnya mereka yang menjadi tulang punggung di rumah orangtuanya. Begitu juga dengan kendaraan, para guru di SMA Negeri 1 Kampar Kiri Hilir sebagian besar memiliki 
kendaraan bermotor dan beberapa orang memiliki mobil, hanya beberapa guru saja yang ketika mengajar naik kendaraan umum. Jaminan pensiun juga diberikan terutama bagi guru PNS, dan setiap guru diberikan jaminan asuransi kesehatan serta diberikan pesangon apabila berhenti mengajar di sekolah tersebut.

Hasil observasi tersebut mengindikasikan bahwa tingkat sosial ekonomi para guru di SMA Negeri 1 Kampar Kiri Hilir tergolong cukup baik.Dengan kondisi sosial ekonomi yang cukup baik tersebut diharapkan dapat menghindarkan guru di SMA Negeri 1 Kampar Kiri Hilir dari serangan stres kronis yaitu stres yang menunjukkan gejala-gejala negatif, seperti penurunan kinerja dan kesehatan.

Akan tetapi berdasarkan hasil prasurvey peneliti pada guru di SMA Negeri 1 Kampar Kiri Hilir ternyata tingkat stres pada gurunya masih relatif tinggi. Indikator adanya asumsi stres pada guruditunjukkan adanya beberapa tanda, seperti suka datang terlambat, bolos mengajar, dalam kegiatan pembelajaran kurang kreatif, bersemangat mengajar yang rendah, lesu, kurang berinteraksi dengan baik dengan para siswanya, suka marah tanpa sebab, mudah tersinggung, tidak sabaran, mencacimaki siswa, dan suka menunda pekerjaan.

Fenomena tersebut menunjukkan bahwa walaupun para guru di SMA Negeri 1Kampar Kiri Hilir tingkat sosial ekonominya cukup baik akan tetapi tetap saja menunjukkan gejala stres pada kerja mereka. Hal ini mengindikasikan adanya penyelewengan dari apa yang dikemukakan para ahli bahwa tingkat sosial ekonomi guru yang baik akan mengurangi stres pada diri guru tersebut. Akan tetapi berdasarkan kenyataan di lapangan yang peneliti temui, ternyata kebalikannya. Walaupun guru telah diupayakan peningkatan kesejahteraannya tetap saja para guru tersebut menunjukkan gejala stres dalam kerjanya.
Berdasarkan fenomena tersebut itulah, peneliti tertarik untuk melakukan penelitian lebih lanjut, mengenai Pengaruh Tingkat Sosial Ekonomi Dengan Stres Pada Guru di SMA Negeri 1Kampar Kiri Hilir. Sehingga melalui penelitian ini diharapkan dapat diketahui lebih mendalam bagaimana dan seberapa besar sebenarnya pengaruh tingkat sosial ekonomi terhadap stres yang dialami para guru yang menjadi problema guru selama ini yang dapat menghambat pencapaian hasil belajar para siswa yang lebih optimal.

Berdasarkan uraian pada latar belakang masalah, selanjutnya diidentifikasi beberapa permasalahan sebagai berikut: (a) Tingkat kesejahteraan guru cukup baik akan tetapi tingkat stres cukup tinggi; (b) Guru memiliki tempat tinggal yang cukup layak akan tetapi stres kerja mereka cukup tinggi; (c) Fasilitas kendaraan dimiliki guru cukup memadai kebanyakan memiliki kendaraan bermotor akan tetapi kinerja mereka tidak memuaskan; (d) Banyak bantuan dari pemerintah untuk guru honorer juga tambahan pendapatan lainnya di luar jam mengajar seperi uang piket dan wali kelas serta transportakan tetapi tetap saja banyak guru yang mengalami stres dalam kerjanya; (e) Guru banyak melakukan pekerjaan sampingan yang dapat menganggu efektivitas dan produktivitas profesinya sebagai guru; (f) Kecilnya gaji yang didapat membuat guru honorer mengajar di tempat lain dari pagi hingga sore; (g) Bantuan yang diberikan pemerintah sering tidak diberikan dengan semestinya terutama kepada guru honor; dan (h) Stres yang dialami guru telah mendekati tingkat tinggi atau stres kronis karena terjadinya penurunan kinerja dan kedisiplinan kerja.

Guna memperoleh ruang lingkup kajian yang lebih jelas dan menghindari terjadinya penafsiran yang berbeda, permasalahan dalam penelitian ini dibatasi pada hal sebagai berikut: (a) Keadaan tingkat sosial ekonomi guru di SMA Negeri 1Kampar Kiri Hilir; (b) Tingkat stres yang 
dialami guru di SMA Negeri 1Kampar Kiri Hilir; dan (c) Hubungan tingkat sosial ekonomi dan stres pada guru di SMA Negeri 1Kampar Kiri Hilir.

Dari uraian permasalahan dan datadata di atas dirumuskan masalah penelitian berikut bagaimanakah pengaruh tingkat sosial ekonomi dan stres pada guru di SMA Negeri 1Kampar Kiri Hilir? apakah ada pengaruh tingkat sosial ekonomi dan stres pada guru di SMA Negeri 1Kampar Kiri Hilir? berapa besar pengaruh tingkat sosial ekonomi dengan stres pada guru di SMA Negeri 1Kampar Kiri Hilir?

Berdasarkan rumusan masalah di atas maka penelitian ini pada dasarnya bertujuan untuk mengembangkan atau mengkaji kebenaran dari suatu pengetahuan.Untuk itu tujuan dan kegunaan dalam penelitian ini adalah untuk mengetahui bagaimana pengaruh tingkat sosial ekonomi guru dan stres pada guru, apakah ada pengaruh tingkat sosial ekonomi guru dan stres pada guru dan seberapa besar pengaruh tingkat sosial ekonomi guru dan stres pada guru di SMA Negeri 1Kampar Kiri Hilir.

\section{LANDASAN TEORI}

\section{Sosial Ekonomi Guru}

Dalam Kamus Besar Bahasa Indonesia yang dimaksud dengan sosial adalah "berkenaan dengan masyarakat" (KBBI, 1997: 958). Sedangkan kata ekonomi diartikan hal-hal yang berhubungan dengan kekayaan, kesejahteraan, sesuatu yang berharga (KBBI, 1997: 251). Sudarsono juga menerjemahkan bahwa sosial ekonomi merupakan segala sesuatu yang berkaitan dengan kekayaan dan kemiskinan suatu masyarakat (Sudarsono, 1990: 131). Berdasarkan pengertian menurut bahasa tersebut, dapat dipahami bahwa yang dimaksud dengan sosial ekonomi guru adalah segala sesuatu yang berkaitan dengan penghasilan guru yang dapat meningkatkan kesejahteraan guru.
Menurut Jalal (1981: 56), sosial ekonomi guru berkaitan dengan kesejahteraan guru baik lahir maupun batin, kedua-duanya merupakan suatu keterkaitan yang erat. Dengan kata lain kesejahteraan lahir akan memberikan kesejahteraan batin, akan tetapi kesejahteraan batin akan sulit muncul apabila tidak didukung oleh kesejahteraan lahir.

Dalam UU RI No. 14 Tahun 2005 tentang guru dan dosen dijelaskan bahwa sosial ekonomi guru merupakan kesejahteraan yang harus dimiliki seorang guru karena profesinya (ForMaPPI, 2008: 49-50). Begitu juga dalam penjelasan Undang-Undang Nomor 20 Tahun 2003 tentang Sistem Pendidikan Nasional pasal 40 ayat 1 dijelaskan bahwa sosial ekonomi guru merupakan kesejahteraan yang harus diberikan kepada guru.

Berdasarkan beberapa pendapat di atas dapat disimpukan bahwa kondisi sosial ekonomi guru merupakan keadaan kesejahteraan guru yang berhubungan dengan pendapatan yang diperolehnya dari profesinya sebagai guru, serta jaminan sosial lainnya.

\section{Bentuk Sosial Ekonomi Guru}

Mengenai bentuk sosial ekonomi guru telah dijelaskan dalam UU RI No. 14 Tahun 2005 tentang guru dan dosen dijelaskan bahwa bentuk sosial ekonomi guru berupa: penghasilan di atas kebutuhan hidup minimum yaitu pendapatan yang cukup untuk memenuhi kebutuhan hidup guru dan keluarganya secara wajar, baik sandang, pangan, papan, kesehatan, pendidikan, rekreasi, maupun jaminan hari tua (ForMaPPI, 2008: 4950).Dan dalam Undang-Undang Nomor 20 Tahun 2003 tentang Sistem Pendidikan Nasional pasal 40 ayat 1 dijelaskan bahwa bentuk sosial ekonomi guru berupa penghasilan atau pendapatan yang diterima seorang guru, yaitu: gaji, jaminan kesehatan dan jaminan hari tua. 
Dengan demikian berdasarkan
undang-undang tersebut dapat disimpulkan bahwa bentuk sosial ekonomi guru berupa: (1) pendapatan yang mencukupi; (2) memiliki jaminan kesehatan; (3) memiliki tempat tinggal yang memadai; dan (4) tunjangan pendidikan bagi anak-anaknya.

\section{Pendapatan Guru}

Dalam Undang-Undang Nomor 20 Tahun 2003 tentang Sistem Pendidikan Nasional pasal 40 ayat 1 disebutkan bahwa pendidik dan tenaga kependidikan berhak memperoleh penghasilan yang patas dan memadai. Dan dalam penjelasan UU Nomor 20 Tahun 2003 tentang Sistem Pendidikan Nasional dijelaskan bahwa yang dimasud dengan penghasilan yang pantas dan memadai adalah "penghasilan yang mencerminkan martabat guru sebagai pendidik yang profesional di atas kebutuhan hidup minimum (KHM)."

Dalam UU RI No. 14 Tahun 2005 tentang guru dan dosen pasal 14 ayat 1 disebutkan bahwa dalam melaksanakan tugas keprofesionalan, guru berhak memperoleh penghasilan di atas kebutuhan hidup minimum (ForMaPPI, 2008: 49-12). Penghasilan di atas kebutuhan hidup minimum meliputi gaji pokok, tunjangan yang melekat pada gaji, serta penghasilan lain berupa tunjangan profesi, tunjangan fungsional, tunjangan khusus, dan maslahat tambahan yang terkait dengan tugasnya sebagai guru yang ditetapkan dengan prinsip penghargaan atas dasar prestasi (ForMaPPI, 2008: 13). Maka berdasarkan Undang-Undang tersebut para guru berhak mendapatan gaji atau penghasilan di atas upah minimum kota yang telah diberlakukan yaitu Rp. 2.095.000 perbulan.

\section{Jaminan Kesehatan}

Jaminan kesehatan merupakan bagian dari sosial ekonomi guru yang berhak diterima seorang guru terkait dengan kesejahteraannya. Seorang guru merupakan seorang pahlawan bangsa yang menjadikan generasi bangsa yang maju, cerdas, dan mampu membangun negaranya. Akan tetapi mereka juga memiliki keterbatasan kekuatan fisik. Terkadang karena terlalu capek memikirkan anak didiknya, tugas lainnya sebagai guru, bebannya dalam keluarga, menimbulkan berbagai kelelahan fisik yang akhirnya timbul berbagai penyakit dalam tubuhnya. Mengingat begitu besar jasanya pada negara, pantas kiranya mereka mendapatkan jaminan kesehatan dan layanan kesehatan yang baik. Untuk itu dalam Undang-Undang Nomor 20 Tahun 2003 tentang Sistem Pendidikan Nasional pasal 40 ayat 1 disebutkan bahwa pendidik dan tenaga kependidikan berhak memperoleh jaminan kesejahteraan sosial yang pantas dan memadai. Dan kesejahteraan sosial yang memadai itu diantaranya adalah jaminan kesehatan.

Problema guru dalam jaminan kesehatan biasanya dialami oleh para guru yang berstatus honorer, seperti guru bantu. Sebagaimana yang ditulis dalam harian Suara Merdeka bahwa Sedikitnya 40 guru bantu dan guru tidak tetap (GTT) dari Kabupaten Demak dan Kota Semarang mengadu ke DPD PGRI Jateng, Jumat (13/2). Mereka mengeluhkan rendahnya gaji bulanan yang diterima dan tidak adanya jaminan kesehatan kerja (Ratna, Suara Merdeka: 2004). Bahkan ada beberapa pendapat yang mengajukan usul agar walaupun tidak bisa gratis dalam jaminan kesehatan para guru mendapat pelayanan kesehatan yang brkualitas tapi berbiaya sangat murah. (http:// iwansyahril.blogspot.com/2006/ ).

\section{Tempat Tinggal}

Seorang guru juga memerlukan kebutuhan akan papan atau tempat tinggal dimana tempat ia dan keluarganya berteduh. Banyak terjadi dalam masyarakat guru tinggal di rumah kontrakan yang kecil dan tidak layak untuk 
didiami seorang guru, apalagi mengingat apa yang dijelaskan dalam Undang-Undang Nomor 20 Tahun 2003 tentang Sistem Pendidikan Nasional bahwa seorang guru berhak mendapatkan penghasilan yang dapat memenuhi kebutuhan hidup diantaranya perumahan atau tempat tinggal yang pantas dan memadai yang mencerminkan martabat guru.

Rasanya tak pantas dan memadai bila seorang guru tinggal di sebuah rumah kontrakan, kecil, lingkungan yang padat, kumuh, yang tidak mencerminkan martabat seorang guru. Untuk itu penyediaan tempat tinggal bagi guru sangat besar artinya dalam upaya peningkatan kesejahteraan guru. Sebagaimana dinyatakan oleh Bujang Rahman bahwa, bagi guru dapat diterapkan alternatif pemberian subsidi dari pemerintah di luar gaji, seperti subsidi rumah. Jika pemberian rumah atau tempat tinggal layak masih tidak memungkinkan diberikan secara gratis maka bisa saja dipikirkan cara lain. Misalnya para guru diberi fasilitas pinjaman dengan bunga yang amat rendah (atau tidak berbunga sama sekali!) dan masa pengembalian selama 25-30 tahun.

\section{Tunjangan Pendidikan Anak}

Dalam Rancangan Undang-Undang Guru dan Dosen sebelum disahkan Departemen Pendidikan Nasional (Depdiknas) dan Komisi X sepakat mencantumkan usulan jaminan pendidikan gratis bagi anak-anak guru dan dosen di satuan pendidikan negeri dalam RUU Guru dan Dosen yang kini tengah dibahas DPR. (http:/ / www.sinarharapan.co.id/ ).

Dirjen Peningkatan Mutu Pendidikan dan Tenaga Pendidik Fasli Djalal mengatakan bahwa peningkatan kesejahteraan guru itu diusulkan sebagai bagian dari pengembangan profesi tenaga pendidik."Harus diakui, kemampuan mereka untuk menyekolahkan anakanaknya terbatas.Sementara, mereka ini orang-orang yang mengerti benar pentingnya pendidikan itu.Supaya dia lebih tenang mengajar orang lain, maka kita tawarkan, bolehkah anak-anak guru dan dosen ini diberi kemudahan untuk bersekolah di tempat orang tuanya bekerja," ujarnya.

Dengan demikian apabila pemerintah memberikan jaminan pendidikan bagi anak-anak guru akan sangat besar artinya bagi guru tersebut, akan meringankan beban hidup sang guru. Ia akan mengajar dengan tenang tanpa harus prihatin memikirkan nasib sekolah anak-anaknya. Walaupun memang tidak bisa memberikan sekolah gratis setidaknya ada kebijakan lain berupa pemberian beasiswa pendidikan bagi anak-anak guru dan dosen tersebut.

\section{Pentingnya Peningkatan Sosial Ekonomi Guru}

Kebutuhan pokok manusia ada yang bersifat jasmani dan rohani. Kebutuhan tersebut merupakan hal yang tidak dapat dihindarkan oleh manusia demikian pula halnya dengan seorang guru. Selain ia mempunyai kewajiban melaksanakan tugasnya dengan sebaik-baiknya, guru juga memiliki hak yang wajib untuk diberikan, meliputi: (1) imbalan jasa yang wajar dan proporsional; (2) rasa aman dalam melaksanakan tugas; (3) kondisi kerja yang kondusif; (4) hubungan antar pribadi yang baik dan kondusif; dan (5) kepastian jenjang karier dalam menuju masa depan.

Guru sebagai tenaga professional, memiliki banyak kebutuhan seperti kebutuhan akan suasana kerja yang menyenangkan, keamanan kerja, fasilitas yang mendukung terlaksananya proses belajar mengajar, imbalan yang memadai dan kesempatan untuk mengembangkan karir. Jika salah satu atau keseluruhan kebutuhan telah terpenuhi, diperkirakan guru akanmewujudkan kinerjanya secara optimal. Dengan demikian tercukupinya kebutuhan yang dimiliki atau dirasakan oleh seseorang termasuk guru akan mempengaruhi kinerja mereka dan akan 
mendorong para guru yang ada dalam organisasi atau lembaga pendidikan untuk bekerja dengan sungguh-sungguh untuk mewujudkan tujuan lembaganya. Sebaliknya, kebutuhan yang kurang mencukupi juga dapat menghambat pelaksanaan pekerjaan itu sendiri.

Seperti halnya pendapat Fullan dalam Supriadi, bahwa sekolah dan pembelajaran di kelas akan menjadi efektif jika dilakukan oleh guru-guru yang profesional dan hal itu akan dapat terjadi apabila: (1) orang-orang yang direkrut sebagai tenaga pegajar adalah orang yang berkualitas; dan (2) tempat kerja (sekolah) diorganisir sedemikian rupa untuk mendorong dan selalu memberikan penghargaan kepada guru-guru yang telah mampu mengajar secara sempurna (Supriadi, 1999: 21). Penghargaan yang dimaksud dapat berupa pujian atau imbalan atau berupa dukungan terhadap pemenuhan kebutuhan guru. Keduanya saling berhubungan erat. Secara profesional kondisi tempat kerja dalam hal ini sekolah yang mampu memberikan penghargaan akan memancing sekaligus memotivasi guru untuk melakukan pembelajaran yang prima dan mereka selalu mempertahankan prestasi secara berkelanjutan.

Sedangkan menurut Surakhmad, faktor mendasar yang terkait erat dengan kinerja professional tenaga pendidik adalah "kepuasan kerja" yang berkaitan dengan "kesejahteraan". Kepuasan ini dilatarbelakangi oleh faktor-faktor, yaitu: (1) imbalan jasa; (2) rasa aman; (3) hubungan pribadi; (4) kondisi lingkungan kerja; dan (5) kesempatan untuk pengembangan dan peningkatan diri.

Dengan demikian berdasarkan beberapa pendapat di atas dapat disimpukan bahwa peningkatan kesejahteraan guru secara langsung maupun tidak langsung berarti juga merupakan suatu upaya peningkatan mutu pendidikan. Guru yang terjamin kesejahteraannya tentu akan rajin dan giat bekerja, dan dalam melaksanakan tugas dan kewajibannya pun akan dilakukan dengan penuh semangat kreativitas tinggi, dan berupaya dengan segala daya untuk meningkatkan hasil pendidikannya. Kesejahteraan guru yang kurang diperhatikan menjadi salah satu faktor yang paling menentukan rendahnya kualitas kinerja guru. Sehingga wajarlah ketika banyak guru yang mempunyai kerja sampingan yang tidak mendukung profesinya guna meningkatkan kesejahteraan hidupnya.

\section{STRES PADA GURU}

\section{Pengertian Stres Pada Guru}

Dalam Kamus Besar Bahasa Indonesia, stres didefinisikan: "suatu keadaan dimana individu mengalami kelelahan fisik, emosional dan mental, atau juga bisa bermakna kelelahan emosional, frustasi, dan keletihan yang terjadi jika rangkaian peristiwa di suatu hubungan, misi, cara hidup, pekerjaan atau bisnis tidak menghasilkan sesuatu yang sesuai dengan harapan" (KBBI, 1997: 180).

Menurut Pestonjee, secara teoritis stres diartikan sebagai sebuah atau beberapa rangsangan pada tekanan yang dialami yang tidak dapat diakomodasikan atau ditahan yang pada akhirnya dapat menyebabkan gangguan atau kerusakan pada kesehatan maupun tingkah laku orang tersebut. Agarwala pada tahun 1979 menyatakan bahwa secara psikologis, stres merupakan hasil dari interaksi antara seorang manusia dengan lingkungan di sekitarnya. Pendapat yang sama juga mendefinisikan bahwa yang dimaksud dengan stres adalah "gangguan atau kekacauan mental dan emosional yang muncul karena tanggapan (respon)."

Menurut Charles D, Spielberger menyebutkan bahwa stres adalah tuntutan-tuntutan eksternal yang mengenai seseorang, misalnya obyekobyek dalam lingkungan atau suatu stimulusyang secara obyektif adalahberbahaya. Stres juga biasa diartikan sebagai tekanan, ketegangan atau 
gangguan yang tidak menyenangkan yang berasal dari luar diri seseorang.

Sedangkan menurut Robbins mendefiniskan stres sebagai suatu kondisi dinamik dimana seseorang individu dikonfrontasikan dengan sebuah peluang, kendala atau tuntutan yang dikaitkan dengan apa yang sangat diinginkan dan hasilnya dapat dipersepsikan sebagai tidak pasti dan penting (Robbins, 2003: 37). Baron \& Greenberg, mendefinisikan stres sebagai reaksi-reaksi emosional dan psikologis yang terjadi pada situasi dimana tujuan individu mendapat halangan dan tidak bisa mengatasinya (Margiati, 1999: 71). Sedangkan Landy memahaminya agak berbeda dengan pakar di atas, ia memandang persoalan ini adalah sebagai ketidakseimbangan keinginan dan kemampuan memenuhinya sehingga menimbulkan konsekuensi penting bagi dirinya.

Secara ringkas pengertian stres dapat digambarkan sebagai berikut:

Keterangan:

$$
\mathbf{S}=\mathbf{P}>\mathbf{R}
$$

S : Stres (stres)

$\mathrm{P}$ : Tekanan (pressure)

$\mathrm{R}$ : sumberdaya (resources).

Maksudnya adalah stres terjadi ketika tekanan kepada individu lebih besar daripada sumber daya yang dimiliki.

Berdasarkan beberapa pendapat tersebut dapat dipahami bahwa yang dimaksud dengan stres adalah tanggapan seseorang terhadap rangsangan atau faktor-faktor di luar dirinya yang menyebabkan terjadinya tekanan yang direaksikan dalam bentuk gangguan baik fisik maupun psikisnya. Atau dengan kata lain stres adalah suatu tekanan/ketegangan yang dialami seseorang karena adanya ketidaksesuaian antara lingkungan dengan sumberdaya yang dimilikinya, sehingga menimbulkan reaksi-reaksi terhadap kondisi tersebut. Apabila harapan dan tuntutan tugas tidak selaras dengan kebutuhan dan kemampuan orang, ia akan mengalami stres.

\section{Tipe dan Tingkatan Stres}

Menurut Hans Selye yang disebut sebagai "bapak" penelitian tentang stres menyatakan bahwa stres ada dua tipe, yaitu stres negatif yang disebut dengan distres yang menghasilkan perilaku karyawan yang disfungsional seperti sering melakukan kesalahan, bersikap acuh dan absen tanpa keterangan. Di sisi lain, stres positif atau disebut eustres yang menciptakan tantangan dan perasaan untuk selalu berprestasi dan beperan sebagai faktor motivator kritis yang akan meningkatkan kinerja karyawan.

Pendapat yang sama juga dikemukakan oleh Terry Gregson bahwa stres ada dua tipe atau bentuk yaitu: 1) distres merupakan aspek tidak baik stres yang dapat menyebabkan kinerja yang tidak baik, menurunya produktivitas, menurunya kreatifitas, berkurangnya inovasi dan gangguan kesehatan seperti sakit kepala, gangguan pencernaan, demam berkepanjangan, sakit leher dan nyeri punggung. 2) eustres merupakan stres yang baik yang dapat meningkatkan kinerja (Gregson, 2007: 27-28).

Berdasarkan kedua pendapat tersebut, stres yang dimaksud dalam penelitian adalah stres tipe kedua yaitu stres negatif atau distres yang membawa kepada hal-hal yang negatif. Untuk mencapai tingkat stres distres tersebut ada beberapa tahapan stres yang merupakan tingkatan stres yang dialami seseorang yaitu: Tahap pertama, yaitu mobilisasi Energi artinya seluruh energi mendadak dikerahkan menghadapi tekanan. Pada tahap ini, seluruh aktifitas fisik tubuh meningkat ditandai dengan detak jangtung dan tekanan darah meningkat, kadangkadang disertai dengan permukaan tangan yang berkeringat. Karenanya tahap stres pertama ini merupakan tingkat stres rendah atau secondary stress.

Tahap kedua, yaitu pengeluaran dan penggunaan energi, terjadi apabila ketika tahap pertama bertahan cukup lama dan tidak ada jalan keluar, sehingga tubuh menggunakan seluruh energi yang 
dimilikinya. Pada tahap kedua ini merupakan tingkat stres sedang dengan gejala: perasaan penuh semangat, konsentrasi tinggi, perasaan tetekan, kegeliasahan, hilangnya ingatan, dan penyakit akut ringan seperti demam dan flu.

Tahap ketiga yaitu penghabisan sisa energi, terjadi apabila tekanan terjadi secara terus menerus selama bertahuntahun. Tahap ketiga ini merupakan tingkat stres yang tinggi atau stres kronis, dimana kebutuhan tubuh terhadap energi melebihi kemampuannya untuk memproduksi, gejala-gejalanya: penyakit jantung, tekanan kejiwaan, insomnia, kesalahan membuat keputusan, perubahan kepribadian dan penurunan kinerja dan produktivitas (Jakcen, 2005: 42-44).

\section{Gejala Stres Pada Guru}

$\begin{array}{ccc}\text { Cary Cooper } & \text { dan Alison } & \text { Straw } \\ \text { mengemukakan } & \text { gejala } & \text { stres }\end{array}$ dapat berupa tanda-tanda berikut ini: (1) Fisik, yaitu nafas memburu, mulut dan kerongkongan kering, tangan lembab, rnerasa panas, otot-otot tegang, pencemaan terganggu, sembelit, letih yang tidak beralasan, sakit kepala, salah urat dan gelisah; (2) Perilaku, yaitu perasaan bingung, cemas dan sedih, jengkel, salah paham, tidak berdaya, tidak mampu berbuat apa-apa, gelisah, gagal, tidak menarik, kehilangan semangat, sulit konsentrasi, sulit berfikir jernih, sulit membuat keputusan, hilangnya kreatifitas, hilangnya gairah dalam penampilan dan hilangnya minat terhadap orang lain; dan (3) Watak dan kepribadian, yaitu sikap hati-hati menjadi cermat yang berlebihan, cemas menjadi lekas panik, kurang percaya diri menjadi rawan,penjengkel menjadi meledak-ledak (Cooper, 1995: 8-15).

Sedangkan gejala stres di tempat kerja, yaitu meliputi: (1) kepuasan kerja rendah; (2) kinerja yang menurun; (3) semangat dan energi menjadi hilang; (4) komunikasi tidak lancar; (5) pengambilan keputusan jelek; (6. kreatifitas dan inovasi kurang; dan (7) bergulat pada tugas-tugas yang tidak produktif (Sculer, 1999: 123).

Hal ini juga diungkapkan oleh Uus Firdaus bahwa gejala stres yaitu: membolos, telat kerja, mudah tersinggung dan keinginan untuk pindah kerja. Randal Schuller telah melakukan penelitian pada karyawan yang mengalami stres yang menunjukkan gejala, penurunan prestasi kerja, peningkatan ketidakhadiran serta tendensi mengalami kecelakaan. Bahkan Jacinta lebih lanjut menyetakan bahwa stres yang berkepanjangan akan menyebabkan ketegangan dan kekuatiran serta kehilangan harapan/mudah putus asa (Sculer, 1999: 123).

Berdasarkan beberapa pendapat tersebut, penulis menyimpulkan bahwa stres merupakan suatu kondisi ketengangan yang dapat terlihat dari tekanan pada fisik dan psikis. Dari tekanan pada fisik dan psikis tersebut muncul suatu sikap atau tindakan yang dapat mengamcam kemampuan seseorang untuk menghadapi lingkungannya.

Dengan demikian guru yang mengalami stres menunjukkan gejala yang dapat mengamcam dan menganggu pelaksanaan kerja mereka, seperti: mudah marah dan agresi, tidak dapat relaks, emosi yang tidak stabil, sikap tidak mau kerjasama, perasaan tidak mampu terlibat, dan kesulitan dalam masalah tidur. Hal ini senada dengan apa yang disampaikan Uus Firdaus bahwa guru yang mengalami stres, akan memiliki efek psikologis yang buruk terhadap rendahnya aspek moral, seperti: membolos, telat kerja, mudah tersinggung, dan keinginan untuk pindah. Konsep diri dan sikap negative muncul sehingga perhatian dan perasaan terhadap orang lain menjadi tumpul.

Selain itu guru yang mengalami stres akan mengalami kelelahan fisik dan mental, dan emosional. Kelelahan fisik seperti; sakit kepala, demam, sakit punggung, tegang pada otot leher dan bahu, sering terkena flu, mual-mual, gelisah.Kelelahan mental seperti; merasa 
tidak dihargai, rasa benci, rasa gagal, tidak peka, sinis, acuh tak acuh, selalu menyalahkan, kurang toleran, konsep diri rendah.Kelelahan emosi seperti; rasa bosan, mudah tersinggung, mengeluh, meratap, suka marah, tidak perduli dengan siswa dan putus asa.

$$
\text { Dengan demikian dapat }
$$

disimpulkan bahwa gejala stres pada guru, yaitu: (1) Gangguan pada kesehatan; mudah pusing, mudah capek, pegal-pegal, demam, sering terkena flu, tekanan darah tinggi, keringat berlebihan, gelisah, mudah lelah tanpa alasan, nafsu makan berkurang, demam, sakit punggung, tegang pada otot leher dan bahu, mengalami kesulitan tidur, gangguan pencernaan, gangguan tenggorokan; (2) Gangguan psikologis; merasa tidak dihargai, rasa benci, rasa gagal, rasa bosan, mudah tersinggung, mengeluh, meratap, suka marah, putus asa, kekuatiran yang berlebihan serta kehilangan harapan/mudah putus asa, mudah lupa, kacau pikirannya, daya ingat menurun, sulit untuk berkonsentrasi, suka melamun berlebihan, pikiran hanya dipenuhi satu pikiran saja, terlalu sensitif, gelisah dan cemas, suasana hati mudah berubah-ubah, sedih, mudah menangis dan depresi, gugup, agresif terhadap orang lain dan mudah bermusuhan serta mudah menyerang, dan kelesuan mental, perasaan bingung, jengkel; (3) Gangguan interpersonal, atau dalam hubungan dengan orang lain; tidak peka, sinis, acuh tak acuh, selalu menyalahkan, kurang toleran, tidak perduli dengan siswa, perhatian dan perasaan terhadap orang lain menjadi tumpul, tidak mau kerjasama, mendiamkan orang lain, kepercayaan pada, orang lain menurun, mudah mengingkari janji pada orang lain, senang mencari kesalahan orang lain atau menyerang dengan kata-kata, menutup diri secara berlebihan, dan mudah menyalahkan orang lain; dan (4) Penurunan kinerja; membolos, telat kerja, keinginan untuk pindah, penurunan prestasi kerja, peningkatan ketidakhadiran, kepuasan kerja rendah, semangat dan energi menjadi hilang, komunikasi tidak lancar, pengambilan keputusan jelek, kreatifitas dan inovasi kurang, bergulat pada tugas-tugas yang tidak produktif.

\section{Sebab-sebab Timbulnya Stres Pada Guru}

Terdapat dua faktor penyebab atau sumber munculnya stres atau stres kerja pada guru, yaitu faktor lingkungan kerja dan faktor personal. Faktor lingkungan kerja dapat berupa kondisi fisik, manajemen kantor maupun hubungan sosial di lingkungan pekerjaan. Sedang faktor personal bisa berupa tipe kepribadian, perisliwa/pengalaman pribadi maupun kondisi sosial-ekonomi keluarga di mana pribadi berada dan mengembangkan diri.Betapapun faktor kedua tidak secara langsung berhubungan dengan kondisi pekerjaan, namun karena dampak yang ditimbulkan pekerjaan cukup besar, maka faktor pribadi ditempatkan sebagai sumber atau penyebab munculnya stress (Endang, 20011: 75).

Menurut Davis dan Newstrom stres kerja disebabkan oleh: (1) Adanya tugas yang terlalu banyak. Banyaknya tugas tidak selalu menjadi penyebab stres, akan menjadi sumber stres bila banyaknya tugas tidak sebanding dengan kemampuan baik fisik maupun keahlian dan waktu yang tersedia bagi karyawan; (2) Supervisor yang kurang pandai. Seorang karyawan dalam menjalankan tugas sehari-harinya biasanya di hawah bimbingan sekaligus mempertanggungjawabkan kepada supervisor. Jika seorang supervisor pandai dan menguasai tugas bawahan, ia akan membimbing dan memberi pengarahan atau instruksi secara baik dan benar; (3) Terbatasnya waktu dalam mengerjakan pekerjaan. Karyawan biasanya mempunyai kemampuan normal menyelesaikan tugas kantor/perusahaan yang dibebankan kepadanya. Kemampuan bcrkaitan dengan keahlian, pcngalaman, dan waktu yang dimiliki. Dalam kondisi tertentu, pihak atasan seringkali 
memberikan tugas dengan waktu yang lerbatas. Akibatnya, karyawan dikejar waktu untuk menyelesaikan tugas sesuai tepat waktu yang ditetapkan atasan; (4) Kurang mendapat tanggungjawab yang memadai. Faktor ini berkaitan dengan hak dan kewajiban karyawan. Atasan sering memberikan tugas kepada bawahannya tanpa diikuti kewenangan (hak) yang memadai. Sehingga, jika harus mengambil keputusan harus berkonsultasi, kadang menyerahkan sepenuhnya pada atasan; (5) Ambisuitas peran. Agar menghasilkan performan yang baik, karyawan perlu mengetahui tujuan dari pekerjaan, apa yang diharapkan untuk dikerjakan serta scope dan tanggungjawab dari pekerjaan mereka. Saat tidak ada kepastian tentang definisi kerja dan apa yang diharapkan dari pekerjaannya akan timbul ambiguitas peran; (6) Perbedaan nilai dengan perusahaan. Situasi ini biasanya terjadi pada para karyawan atau manajer yang mempunyai prinsip yang berkaitan dengan profesi yang digeluti maupun prinsip kemanusiaan yang dijunjung tinggi (altruisme); (7) Frustrasi. Dalam lingkungan kerja, perasaan frustrasi memang bisa disebabkan banyak faktor. Faktor yang diduga berkaitan dengan frustrasi kerja adalah terhambatnya promosi, ketidakjelasan tugas dan wewenang sertapenilaian/ evaluasi staf, ketidak-puasan gaji yang diterima; dan (8) Perubahan tipe pekerjaan, khususnya jika hal tersebut tidak umum. Situasi ini bisa timbul akibat mutasi yang tidak sesuai dengan keahlian dan jenjang karir yang di lalui atau mutasi pada perusahaan lain, meskipun dalam satu grup namun lokasinya dan status jabatan serta status perusahaannya berada di bawah perusahaan pertama.

Berdasarkan pendapat tersebut secara ringkas dapat disimpulkan bahwa stres kerja timbul disebabkan tiga faktor utama yaitu: (1) stres yang bersumber dari pekerjaan; (2) stres yang bersumber dari hubungan anta pribadi, dan (3) stres yang bersumber dari kesalahan yang timbul dalam kehidupan pribadi.

Adapun stres yang dialami guru menurut Sarartri Wilonoyudho, menyebutkan bahwa guru mengalami dua macam stres struktural. Pada tataran mikro, jelas terkait dengan kondisi sosioekonomi (Wilonoyudho, 2001: 4). Guruguru di kota-kota besar menghadapi paradoks kehidupan nyata, dimana mereka mendidik anak-anak orang kaya, yang memiliki kemudahan fasilitas hidup, sedangkan guru itu sendiri kesulitan dalam menyekolahkan anak-anaknya dan untuk memenuhi kebutuhan hidup. Sedangkan guru di pedesaan mengalami masalah dimensi lain, di mana ia harus berjalan kaki untuk menuju sekolah dengan jarak yang cukup jauh.

Dengan demikian dapat disimpulkan bahwa penyebab timbulnya stres pada guru dapat bermacam-macam, tergantung pada bagaimana guru tersebut merespon segala tekanan dan tuntutan dari lingkunganya. Apabila dihubungkan dengan pendapat-pendapat sebelumnya tentang penyebab stres, maka stres pada guru dapat disebabkan stres yang bersumber dari pekerjaan, stres yang bersumber dari hubungan anta pribadi, dan stres yang bersumber dari kesalahan yang timbul dalam kehidupan pribadi.

\section{Dampak Stres Pada Guru}

Secara umum dampak stres menurut Rendall Schuller, stres yang dihadapi oleh karyawan berkorelasi dengan penurunan prestasi kerja, eningkatan ketidakhadiran kerja serta tendesi mengalami kecelakaan. Secara singkat beberapa dampak negatif yang ditimbulkan oleh stres kerja dapat berupa: (1) Terjadinya kekacauan, hambatan baik dalam manajemen maupun operasional kerja; (2) Mengganggu kenormalan aktivitas kerja; (3) Menurunkan tingkat produktivitas; dan (4) Menurunkan pemasukan dan keuntungan perusahaan.Kerugian financial yang 
dialami perusahaan karena tidak imbangnya antara produktivitas dengan biaya yang dikeluarkan untuk membayar gaji, tunjangan, dan fasilitas lainnya.

Sedangkan dampak stres pada guru ada yang menguntungkan dan ada yang merugikan bagi sekolah. Namun pada taraf tertentu pengaruh yang menguntungkan sekolah diharapkan akan memacu guru untuk dapat menyelesaikan pekerjaan dengan sebaik-baiknya. Reaksi terhadap stres dapat merupakan reaksi bersifat psikis maupun fisik. Biasanya guru yang stres akan menunjukkan perubahan perilaku. Perubahan perilaku tcrjadi pada diri manusia sebagai usaha mengatasi stres. Usaha mengatasi stres dapat berupa perilaku melawan stres (flight) atau freeze (berdiam diri).

\section{Upaya Menanggulangi Stres Pada Guru}

Stres dalam pekerjaan dapat dicegah timbulnya dan dapat dihadapi tanpa memperoleh dampaknya yang negatif, begitu pula hanya dengan stres yang dialami seorang guru dapat ditangggulangi sehingga tidak berdampak buruk pada diri guru tersebut.Upaya untuk menanggulangi stres dapat dilakukan melalui suatu manajemen stres.Manajemen stres lebih daripada sekedar mengatasinya, yakni belajar menanggulanginya secara adaptif dan efektif. Hampir sama pentingnya untuk mengetahui apa yang tidak boleh dilakukan dan apa yang harus dicoba.

Suprihanto mengatakan bahwa dari sudut pandang organisasi, manajemen mungkin tidak khawatir jika karyawannya mengalami stres. Maka manajemen mungkin akan berpikir untuk memberikan tugas yang menyertakan stres ringan bagi karyawan untuk memberikan dorongan bagi karyawan, namun sebaliknya itu akan dirasakan sebagai tekanan oleh si pekerja (Suprihanto, 2003: 23-24).

Langkah awal mengelola stres adalah dengan memahami sejak dini gejalagejala stres yang terjadi, langkah berikutnya mencari penyebab stres.Jika dua langkah tersebut sudah dilakukan maka berikutnya menghdapai dan mengurangi stres itu sendiri.Robins menjelaskan ada dua pendekatan yang bisa dilakukan dalam mengelola stres, yaitu pendekatan individu dan pendekatan organisasi. Pendekatan yang tepat dalam mengelola stres, ada dua pendekatan yaitu pendekatan individu dan pendekatan organisasi.

\section{Pendekatan Individual}

Seorang karyawan dapat berusaha sendiri untuk mongurangi level stresnya. Strategi yang bersifat individual yang cukup efektif yaitu; pengelolaan waktu, latihan fisik, latihan relaksasi, dan dukungan sosial. Dengan pengelolaan waktu yang baik maka seorang karyawan dapat menyelesaikan tugas dengan baik, tanpa adanya tuntutan kerja yang tergesagesa.Dengan latihan fisik dapat meningkatkan kondisi tubuh agar lebih prima sehingga mampu menghadapi tuntutan tugas yangberat. Selain itu untuk mengurangi sires yang dihadapi pekerja pcrlu dilakukan kegiatan-kegiatan santai. Dan sebagai stratcgi terakhir untuk mengurangi stresadalah dengan roengumpulkan sahabat, kolega, keluarga yang akan dapat memberikan dukungan dan saran-saran bagi dirinya.

\section{Pendekatan Organisasional}

Beberapa penyebab stres adalah tuntutan dari tugas dan peran serta struktur organisasi yang scmuanya dikendalikan oleh manajemen, schingga faktor-faktor itu dapat diubah.Oleh karena itu strategi-strategi yang mungkin digunakan oleh manajemen untuk mengurangi stres karyawannya adalah melalui seleksi dan penempatan, penetapan tujuan, redesain pekerjaan, pengambilan keputusan partisipatif, komunikasi organisasional, dan program kesejahteraan. Melalui strategi tersebut akan menyebabkan karyawan memperoleh pekerjaan yang sesuai dengan 
kemampuannya dan mereka bekerja untuk tujuan yang mereka inginkan serta adanya hubungan interpersonal yang sehat serta perawatan terhadap kondisi fisik dan mental (Robins, 2003: 54).

Sedangkan Firdaus menyatakan sebaiknya guru yang mengalami stres dapat ditanggulangi dengan cara mencegah munculnya stres. Sebagai alternative yang harus dilakukan adalah: (1) menjaga kesehatan fisik dengan olah raga rutin, makanan yang halal dan baik; (2) refresing, reklreasi, hiburan untuk menghilangkan kepenatan; (3) meningkatkan hubungan yang harmonis dengan orang lain; (4) meningkatkan wawasan dengan membaca, menulis dan ikut kegiatan yang bermanfaat; dan (5) jangan lupa untuk berdoa, takwa dan tawakal kepada Allah. Dan menurut Margiati juga menambahkan bahwa stres pada guru dapat dikurangi dengan meningkatkan kesejahteraan guru.

Adapun dalam ajaran Islam, Allah mengajarkan kepada umat-Nya bahwa untuk menanggulangi stres dengan selalu mawas diri terhadap apa yang menimpa diri kita dan jangan membuat kita sampai putus asa sehingga bisa menimbulkan dampak lain yang lebih parah semacam stres kronis. Apapun yang kita alami harus diantisipasi dengan kekuatan mental dalam menerimanya. Jika kita kembali pada agama, maka sabar, optimis, berdoa dan berusaha mencari solusi terbaik adalah jalan yang harus kita tempuh.

Berdasarkan ayat di atas menegaskan kepada umat muslim bahwa stres yang dialami seseorang termasuk yang dialami guru dapat diatasi dengan tetap mendekati diri kepada Allah. Jauh dari Allah atau agama berarti akan semakin menambah dan memperbesar stres. Sebagaimana yang dikemukakan Zakiah Daradjat bahwa dengan agama dapat memberikan bimbingan dalam hidup, menolong dalam menghadapi kesukaran, dan menetramkan batin (Daradjat, 1995: 56).

\section{Hubungan Sosial Ekonomi dan Stres Pada Guru}

Menurut beberapa ahli tingkat sosial ekonomi guru memiliki hubungan yang sangat erat dengan stres pada guru yaitu merupakan salah satu faktor penyebab timbul dan meningkatnya tingkat stres pada guru. Sebagaimana yang dikemukakan Muzayyin Arifin bahwa kurangnya bantuan kesejahteraan dan gaji yang kurang memadai merupakan problema major bagi seorang guru baik yang tinggal di pedesaan maupun di kota (Arifin, 2007: 111-112). Pendapat lain juga menyatakan bahwa diantara beberapa faktor yang menyebabkan seseorang menjadi stres adalah faktor sosial ekonomi, yang dalam hal ini adalah ketidakpastian ekonomi. Menurut Marsetio dalam Surat Kabar Harian Kompas menyatakan bahwa stres yang dialami guru didominasi karena pemotongan gaji dan kurangnya subsidi kesejahteraan guru (Marsetio, 2008, 45). Pendapat lain juga menyatakan bahwa stres disebabkan salah satunya adalah faktor kondisi ekonomi. Margiati juga menambahkan bahwa stres pada guru dapat dikurangi dengan meningkatkan kesejahteraan guru.

Sarartri Wilonoyudho, menyebutkan bahwa guru mengalami dua macam stres struktural. Pada tataran mikro, jelas terkait dengan kondisi sosio-ekonomi (Wilonoyudho, 2001: 4). Di beberapa daerah lain, stres guru diakibatkan oleh pemotongan gaji guru yang tidak proporsional. Sedangkan hasil beberapa penelitian di Malasyia, stres bersumber dari beban kerja yang berlebihan. Sementara gaji guru pas-pasan di sisi lain kebutuhan membumbung tinggi. Tuntutan hidup yang demikian besar pada satu sisi, sementara di sisi lain tanggung jawab dan beban moral yang dipikul sebagai pengajar dan pendidik sangat besar sering mengakibatkan stres/ tekanan mental pada guru.“Untuk menghindari stres mereka, diperlukan peningkatan kesejahteraan dan penyediaan sarana dan prasarana yang 
memadai sehingga tercipta kepuasan kerja."

Berdasarkan beberapa pendapat tersebut dapat disimpulkan bahwa tingkat sosial ekonomi guru memiliki hubungan yang sangat erat terhadap timbulnya stres pada guru. Atau dengan kata lain tingkat kesejahteraan guru akan berpengaruh terhadap tingkat stres pada guru, semakin sejahtera kondisi ekonomi guru tersebut maka akan berkurang tingkat stres dalam dirinya. Untuk itu pemberian subsidi berupa pendapatan yang mencukupi, memberikan kesejahteraan lainnya seperti jaminan kesehatan, perumahan, kendaraan, pensiun, asuransi, tunjangan pendidikan bagi anak-anaknya, merupakan hal sangat perlu ditingkatkan dalam upaya menanggulangi stres dalam diri guru tersebut.

\section{METODOLOGI PENELITIAN}

Dalam penelitian ini pendekatan yang digunakan adalah pendekatan penelitian kuantitatif karena dalam penelitian ini yang akan dilakukan adalah untuk menguji seberapa tinggi atau rendahnya hubungan yang bersifat pengaruh antara variabel tingkat sosial ekonomi guru dengan variabel stres pada guru. Dengan demikian dalam penelitian ini terdapat satu variebal independent atau variabel bebas yaitu tingkat sosial ekonomi guru dan satu variabel dependen atau terikat yaitu stres pada guru.Sebagaimana dikemukakan Margono (1997: 45-46) bahwa tujuan penelitian kuantitatif adalah untuk menguji teori, mengukuhkan fakta-fakta, dan untuk menunjukkan hubungan-hubungan di antara variable.

Karena dalam penelitian ini menggunakan pendekatan penelitian kuantitatif, maka metode pengumpulan data yang digunakan adalahangket, wawancara dan dokumentasi.Angket digunakan untuk mengungkapkan variabel bebas, terutama tentang, kondisi sosial ekonomi guru dan tingkat stres pada guru di SMA Negeri 1 Kampar Kiri Hilir.Angket dibuat dalam bentuk pertanyaan dengan tiga alternatif jawaban.Jawaban setiap item instrument menggunakan skala likert yang digunakan untuk mengukur sikap, pendapat dan persepsi seseorang atau sekelompok orang tentang fenomena sosial yang mempunyai gradasi dari sangat positif sampai sangat negatif (Sugiyono, 2008: 134-135). Sedangkan wawancara digunakan untuk memperoleh informasi secara langsung dengan guru, siswa, kepala sekolah tentang kondisi sosial ekonomi guru, stres yang dialami guru, keadaan proses pembelajaran dan sekolah. Kemudian dokumentasi digunakan untuk memperoleh data mengenai guru, siswa, sekolah, sarana prasarana pendidikan, tunjagan yang diperoleh guru, kegiatan pembelajaran guru, aktivitas guru, absensi guru, dan sebagainya.

Sesuai dengan jenis penelitian ini, maka sebelum teknik statistic yang digunakan untuk menguji hipotesis diterapkan, terlebih dahulu data dideskripsikan dengan mengungkapkan nilai rata-rata, standar deviasi, modus, dan median, juga disajikan daftar distribusi frekuensi, dan histogram. Selanjutnya asumsi-asumsi yang digunakan dibuktikan melalui pengujian persyaratan analisis.Pengujian persyaratan analisis dalam hal ini meliputi uji normalitas dan homogenitas data.Uji normalitas data dilakukan dengan menggunakan uji normalitas dengan menggunakan teknik Chi Kuadrat $\left(\lambda^{2}\right)$, yang kemudian dalam perhitungannya menggunakan bantuan computer yaitu program SPSS 20. Pengujian ini bertujuan untuk mengetahui apakah data penelitian untuk variabel tingkat sosial ekonomi guru dan stres pada guru memiliki sebaran yang normal atau tidak.

Sementara pengujian homogenitas data adalah pengujian mengenai sama tidaknya variansi-variansi dua buah distribusi atau lebih. Untuk menguji homogenitas varians variabel tingkat sosial ekonomi guru $(\mathrm{X})$ dan variabel stres pada guru (Y) dilakukan dengan menggunakan 
Uji-F.Dengan ketentuan jika $\mathrm{F}_{\text {hitung }}<\mathrm{F}_{\text {tabel }}$, maka varians dari kelompok tersebut homogen. Dalam aplikasinya peneliti menggunakan program SPSS 20 dengan kriteria uji apabila nilai $r$ lebih kecil atau sama dengan $\Leftrightarrow$ dari tingkat $\alpha$ yang ditentukan, maka skor-skor pada variabel tersebut menyebar secara homogen (Sugioyono, 2008: 259).

Kemudian setelah melakukan ujian normalitas dan homogenitas maka langkah selajutnya melakukan uji hipotesis dengan teknik korelasi dan regresi sederhana. Rumusnya sebagaimana berikut:

$$
r=\frac{\sum X Y-\frac{\left(\sum X\right)\left(\sum Y\right)}{n}}{\sqrt{\left[X^{2}-\frac{\left(\sum X\right)^{2}}{n}\right]\left[\sum Y^{2}-\frac{\left(\sum Y\right)^{2}}{n}\right]}}
$$

Keterangan:

$\mathrm{r}=$ koefisien korelasi

$\Sigma \mathrm{X}=$ jumlah skor dalam sebaran $\mathrm{X}$

$\Sigma \mathrm{Y}=$ jumlah skor dalam sebaran $\mathrm{Y}$

$\Sigma \mathrm{XY}=$ jumlah hasil skor $\mathrm{X}$ dengan skor $\mathrm{Y}$ yang berpasangan

$\Sigma \mathrm{X}^{2}=$ jumlah skor yang dikuadratkan dalam sebaran $\mathrm{X}$

$\Sigma \mathrm{Y}^{2}=$ jumlah skor yang dikuadratkan dalam sebaran $Y$

$\mathrm{n}=$ banyaknya subjek skor $\mathrm{X}$ dan skor $\mathrm{Y}$ yang berpasangan.

Untuk melihat atau mengetahui tingkat capaian responden terhadap masing-masing variabel berdasarkan angket yang disebarkan digunakan rumus:

$$
\frac{\sum S k o r}{\sum \text { Respoder } \times \sum \text { buti } \times \sum \text { bobottendiggi }} \times 10 \%
$$

Pengkatagorian nilai pencapaian responden pada variabel tingkat sosial ekonomi guru digunakan klasifikasi sebagai berikut:

$90-100 \%$ : Sangat baik

$80-89 \%$ : Baik

$65-79 \%$ : Cukup

$55-64 \%$ : Kurang baik

$0-54 \%$ : Tidak baik.
Untuk pengkatagorian nilai variabel stres pada guru digunakan klasifikasi sebagai berikut:

$90-100 \%$ : sangat rendah

$80-89 \%$ : rendah

$65-79 \%$ : cukup

$55-64 \%$ : tinggi

$0-54 \%$ : sangat tinggi

Untuk memudahkan perhitungan dalam menganalisis data dengan mempergunakan berbagai rumus tersebut, penulis menggunakan alat bantu komputer dengan fasilitas program SPSS 20.

\section{HASIL DAN PEMBAHASAN \\ Profil SMAN 1 Kampar Kiri Hilir}

SMAN 1 Kampar Kiri Hilir Kabupaten Kampar didirikan pada tahun 2002. Sekolah ini didirikan sebagai suatu wujud serta dalam pembangunan generasi muda dan kepedulian dalam meningkatkan mutu pendidikan, baik bidang IPTEK maupun IMTAQ, serta membekali siswa dengan keterampilan melalui penyaluran minat dan pengembangan bakat, sebagai bekal masa depan siswa.Sekolah terletak Jl. Lintas Pekanbaru - Lipatkain KM. 35.Nama kepala sekolahnya Hefnofita Yuliani, S.Pd. sekolah ini terakreditasi B.

Kepemilikan Tanah/Bangunan dari dana Hibah. Luas Tanah/Status10.610 M²dan Luas bangunan sekitar $746 \mathrm{M}^{2}$.

Sebagai lembaga pendidikan SMAN 1 Kampar Kiri Hilir memiliki visi dan misi yang sangat relevan dengan cita-cita pendidikan nasional. Adapun visi dan misi yang dirumuskan adalah:

Visi :Unggul dan Berprestasi dengan Imtaq dan Iptek. Dengan indikator: (a) Unggul dalam perolehan nilai UAS dan UAN; (b) Berprestasi dan olah raga; (c) Unggul dalam disiplin; (d) Unggul dalam kesenian; (e) Berprestasi dalam kesenian; (f) Unggul dalam Penguasaan Komputer; dan (g) Unggul dalam Bahasa Inggris.

Misi: (a) Meningkatkan rata-rata UAS dan UAN dengan mengintensikan pembelajaran bimbingan; (b) Menyediakan 
sarana serta memotivasi siswa untuk mengikuti latihan sepak bola secara rutin; (c) Membina menumbuhkan kembangkan disiplin terhadap semua warga sekolah melalui ekstrakurikuler kepramukaan; (d) Menanamkan penghayatan terhadap pelajaran agama sehingga menjadi sumber moral dalam kehidupannya melalui bimbingan kerohanian; (e) Menyediakan wahana kegiatan kesenian; (f) Menyediakan media pembelajaran komputer; dan (g) Mengadakan les Bahasa Inggris.

\section{Deskripsidan Analisis Data}

Pada penelitian ini terdapat 2 variabel, yaitu variabel Tingkat Sosial Ekonomi dan Stres Pada Guru. Dimana variabel Tingkat Sosial Ekonomi memiliki 14 item pernyataan dan Stres Pada Guru sebanyak 17 pernyataan, sehingga kedua variabel itu berjumlah 31 itempernyataan. Dari perhitungan angket hasil jawaban guru terhadap pernyataan dan pertanyaan yang ada dalam kuesioner maka dapat dilakukan analisis data yaitu untuk mendapatkan hasil dari pengaruh tingkat sosial ekonomi dengan stres pada guru.

Analisis data adalah proses penyederhanan data kedalam bentuk yang lebih mudah dibaca dan di interpretasikan, dalam proses ini digunakan statistik yang salah satu fungsinya adalah untuk menyederhanakan data penelitian yang

Tabel 2 besar jumlahnya menjadi informasi yang lebih sederhana dan mudah dipahami.

Tekhnik analisis data yang digunakan sesuai dengan tujuan yang hendak dicapai. Berdasarkan jenis data yang dikumpulkan yaitu data kuantitatif, maka tekhnik yang digunakan adalah analisis statistik sebagai berikut:

Prosentase ialah, data diprosentasekan setelah ditabulasi dalam jumlah frekuensi jawaban responden untuk setiap alternatif jawaban dengan rumus:

$$
P=\underset{N}{F} X 100 \%
$$

Keterangan: $\mathrm{P}=$ Prosentase untuk setiap kategori jawaban

$\mathrm{F}=$ Frekuensi jawaban responden

$\mathrm{N}=$ Number of clases

Kemudian rumus statistik yang digunakan untuk mencari dan mengetahui ada tidaknya pengaruh antara kedua variabel ialah rumus korelasi product moment, karena dalam penelitian ini terdapat dua variabel yang perlu mendapat kejelasan, apakah terdapat pengaruh antara kedua variabel atau sama sekali tidak terdapat pengaruh. Kedua variabel tersebut ialah Pengaruh Tingkat Sosial Ekonomi dengan Stres pada Guru SMAN 1 Kampar Kiri Hilir.

\section{Nilai Korelasi Antara Variabel X dan Variabel Y}

\begin{tabular}{cccccc}
\hline $\mathbf{N}$ & $\mathbf{X}$ & $\mathbf{Y}$ & $\mathbf{X Y}$ & $\mathbf{X}^{\mathbf{2}}$ & $\mathbf{Y}^{\mathbf{2}}$ \\
\hline 1 & 48 & 46 & 2208 & 2304 & 2116 \\
\hline 2 & 46 & 46 & 2116 & 2116 & 2116 \\
\hline 3 & 46 & 46 & 2116 & 2116 & 2116 \\
\hline 4 & 48 & 45 & 2160 & 2304 & 2025 \\
\hline 5 & 46 & 44 & 2024 & 2116 & 1936 \\
\hline 6 & 46 & 44 & 2024 & 2025 & 1936 \\
\hline 7 & 45 & 44 & 1980 & 2025 & 1936 \\
\hline 8 & 45 & 44 & 1980 & 2025 & 1936 \\
\hline 9 & 45 & 43 & 1935 & 2025 & 1849 \\
\hline 10 & 45 & 43 & 1935 & 2025 & 1849 \\
\hline
\end{tabular}




\begin{tabular}{rrrrrr}
\hline 12 & 45 & 41 & 1845 & 2025 & 1681 \\
\hline 13 & 45 & 40 & 1800 & 2025 & 1600 \\
\hline 14 & 42 & 39 & 1638 & 1764 & 1521 \\
\hline 15 & 42 & 41 & 1722 & 1764 & 1681 \\
\hline 16 & 45 & 42 & 1890 & 2025 & 1764 \\
\hline 17 & 45 & 40 & 1800 & 2025 & 1600 \\
\hline 18 & 38 & 46 & 1748 & 1444 & 2116 \\
\hline 19 & 41 & 46 & 1886 & 1681 & 2116 \\
\hline 20 & 32 & 44 & 1408 & 1024 & 1936 \\
\hline 21 & 34 & 41 & 1394 & 1156 & 1681 \\
\hline 22 & 29 & 39 & 1131 & 841 & 1521 \\
\hline 23 & 24 & 39 & 936 & 576 & 1521 \\
\hline 24 & 22 & 38 & 836 & 484 & 1296 \\
\hline 25 & 25 & 36 & 900 & 625 & 1296 \\
\hline 26 & 21 & 36 & 756 & 441 & 1296 \\
\hline 27 & 24 & 36 & 864 & 576 & 1296 \\
\hline 28 & 22 & 36 & 792 & 484 & 1296 \\
\hline 29 & 25 & 36 & 900 & 625 & $2 \mathbf{Y}^{\mathbf{2}}=\mathbf{5 1 7 0 9}$ \\
\hline 30 & 22 & 36 & 792 & 484 & \\
\hline Jlh & $\sum \mathbf{X = 1 1 2 8}$ & $\sum \mathbf{Y = 1 2 4 1}$ & $\sum \mathbf{X Y = 4 7 9 6}$ & $\sum \mathbf{X}^{\mathbf{2}}=\mathbf{4 5 2 6 6}$ & \\
\hline
\end{tabular}

Dari tabel diatas diketahui data sebagai berikut

\begin{tabular}{|l|l|}
\hline $\mathrm{N}=30$ & $\Sigma \mathrm{XY}=47496$ \\
$\Sigma \mathrm{X}=1128$ & $\Sigma \mathrm{X}^{2}=45266$ \\
$\Sigma \mathrm{Y}=1241$ & $\Sigma \mathrm{Y}^{2}=51709$ \\
\hline
\end{tabular}

Selanjutnya data di atas akan diuji keabsahannya dengan rumus product moment untuk mengetahui tingkat korelasi variabel, yaitu:

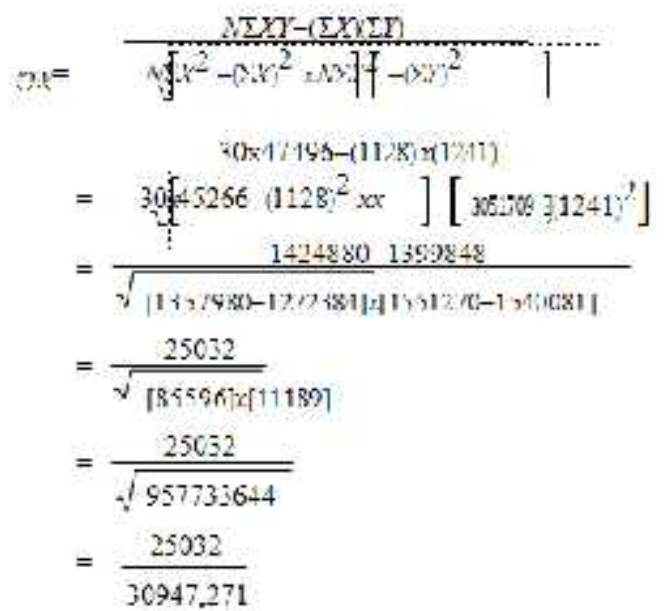

Apabila hasil di atas diinterpretasikan secara sederhana dengan mencocokan hasil perhitungan dengan angka indek korelasi $\mathrm{r}$ Product Moment, ternyata besarnya rxy yang diperoleh terletak antara dari 0,70-0,90 yang berarti variabel $\mathrm{X}$ dan variabel $\mathrm{Y}$ terdapat korelasi yang kuat atau tinggi.

Selanjutnya untuk mengetahui apakah itu signifikan atau tidak, maka $r$ hasil perhitungan dibandingkan dengan rtabel. Dan sebelum membandingkan terlebih dahulu dicari derajat kebebasannya atau df (degree of freedom) dengan menggunakan rumus:

$$
\begin{aligned}
\mathrm{df} & =\mathrm{N}-\mathrm{r} \\
& =30-2 \\
& =28
\end{aligned}
$$

Dengan df sebesar 28 jika dikonsultasikan dengan " $r$ ", masing-masing untuk " $r$ " $5 \%$ sebesar 0,374 dan $1 \%$ sebesar 0,478, jika dilihat dari harga " $r$ " tabel, ternyata rxy lebih besar daripada harga " $\mathrm{r}$ " tabel baik dari taraf signifikansi $5 \%$ maupun 1\%. Dengan demikian hipotesa nol (Ho) ditolak, dan hipotesa alternaif (Ha) diterima. Artinya terdapat 
korelasi yang signifikan antara tingkat sosial ekonomi dengan stres pada guru.

Selanjutnya, untuk mengetahui seberapa besar kontribusi (sumbangsih) yang diberikan variabel $\mathrm{X}$ terhadap variabel Y, maka harus diketahui terlebih dahulu suatu koefisien yang disebut dengan coefficient of determination (korelasi penentu). Denganrumus:

$$
\begin{aligned}
\mathrm{KD} & =\operatorname{rxy}^{2} \times 100 \% \\
& =0,80^{2} \times 100 \% \\
& =0,64 \times 100 \% \\
& =64
\end{aligned}
$$

Dari perhitungan di atas diperoleh hasil KD sebesar 64\%. Ini berarti variabel X (tingkat sosial ekonomi guru) memberikan kontribusi sebesar $64 \%$ terhadap mengurangi variabel $Y$ (stres pada guru) dan 26\% dipengaruhi oleh faktor lain.

\section{KESIMPULAN}

Setelah mempelajari dan menganalisa berbagai masalah dalam penelitian yang berjudul HubunganTingkat SosialEkonomiDenganStres Pada Guru di SMAN 1 Kampar Kiri Hilir Kabupaten Kampar Provinsi Riau penulis mengemukakan beberapa temuan yaitu stres pada guru di SMAN 1 Kampar Kiri Hilir Kabupaten Kampar berada pada garis tinggi. Sebab dari data angket yang diinput dari lapangan guru terlihat masih ada yang menganggap limpahan tugas yang semakin komplek mulai dari tugas sekolah sampai kerja tambahan di luar sekolah membuat kesehatan sering terganggu. Memandang usia yang semakin bertambah juga masih ada terdapat guru yang menganggapnya mengurangi produktivitas.

Kemudian, akibat banyaknya yang menyita perhatian guru di luar atau aktivitas tambahan selain mengajar dari data yang ada guru kelihatannya masih belum sepenuhnya beranggapan saat di sekolah sesuatu yang menyenangkan bahkan tugas-tugas sekolah masih menjadi kebiasaan di bawah ke rumah untuk dikerjakan malam hari, yang pada akhir guru kurang dapat mengembangkan diri karena waktunya tersita oleh aktivitas yang tidak terkait langsung dengan statusnya sebagai guru, padahal tugas pokoknya adalah guru terutama guru yang berstatus pegawai negeri (PNS).

Selain itu, pengendalian emosi sangat dipengaruhi oleh keadaan guru sehingga siswa yang bertingkah sering menjadi sasaran amukan di kelas. Sedangkan hubungan tingkat sosial ekonomi dengan stres pada guru di SMAN 1 Kampar Kiri Hilir Kabupaten Kampar memiliki pengaruh yang positif dan signifikan. Hal ini terlihat dalam hasil penelitian yang dilakukan dimana tingkat sosial ekonomi guru setengahnya berada dalam tingkat menengah kebawah. Ini berdampak pada stres guru yang berada pada tingkat sedang. Hal ini terlihat dalam hasil penelitian, keduanya berada dalam rentang 0,70-0,90 yaitu korelasinya sangat tinggi. Hal ini ditunjukkan pula dengan hasil penelitian yang menyatakan bahwa rxy $>$ rt, dimana rxy pada taraf signifikan $5 \%=0,374$ dan pada taraf signifikansi $1 \%=0,478$. Jadi, rxy $>$ rt $5 \%=0,374>0,478$, karena rxy lebih besar dari rt, maka hipotesa alternative (Ha) yang menyatakan adanya pengaruh positif yang signifikan antara tingkat sosial ekonomi dengan stres pada guru diterima, sementara Ho ditolak, maksudnya semangkin tinggi tingkat sosial ekonomi guru, maka akan semakin rendah tingkat stres pada guru.

\section{DAFTAR RUJUKAN}

Arifin, Muzayyin. 2007. Kapita Selekta Pendidikan Islam. Jakarta: Bumi Aksara.

Cooper, Cary dan Straw, Alison. 1995. Stress Management. Jakarta: Kesain Blanch.

Daradjat, Zakiah. 1995. Peranan Agama dalam Kesehatan Mental. Jakarta: Gunung Agung. 
Departemen Pendidikan dan Kebudayaan. 1997. Kamus Besar Bahasa Indonesia. Jakarta: Balai Pustaka.

Departemen Pendidikan Nasional. 2002. KamusBesar Bahasa Indonesia. Jakarta: Balai Pustaka.

Endang, Dwiyanti. Stres Kerja di Lingkungan DPRD; Studi tentang Anggota DPRD di Kota Surabaya, Malang dan Kabupaten Jember, Jurnal Masyarakat, Kebudayaandan Politik. Surabaya: Fakultas Kesehatan Masyarakat Universitas Air langga.

ForMaPPI. 2008. Undang-Undang RI Nomor 14 Tahun 2005 tentang Guru dan Dosen. Lampung: ForMaPPI Lampung.

Jacken. T., 2005. Jinakkan Stres Kiat Hidup Bebas Tekanan. Bandung: Nexx Media.

Jalal [et.al.]., 1981. Reformasi Pendidikan Dalam Kontek. Jakarta: Gramedia Competindo.

LA., Hartono. 2007. Stresdan Stroke. Yogyakarta: Kanisius.

Lulus, Margiati. 1999. Stres Kerja; Latar Belakang Penyebabdan Alternatif Pemecahannya, Jurnal Masyarakat, Kebudayaan dan Politik. Surabaya: Fakultas Kesehatan Masyarakat Universitas Air langga.

Marsetio, Surat Kabar Harian Kompas, Pungutan Penyebab Terbesar Guru Stres, com. 26 April 2008.
P., Robbins. 2003. Perilaku Organisasi, Konsep dan Aplikasi. Jakarta: Gramedia.

S., Margono. 1997. Meodologi Penelitian Pendidikan. Jakarta, Rineka Cipta.

Wilonoyudho, Sarartru. Merenungkan Perjalanan Hidup Guru, Kompas Cyber Media, 12 September 2001.

Sculer.Randal S., Personnel and Human Resourches Management, Ney York University: KellongBrokvard, 1999.

Sudarsono. 1990. Kenakalan Remaja. Jakarta: Rineka Cipta.

Nana, Sudjana. 1991. Tuntunan Penyusunan Karya Ilmiah, Bandung: Sinar Baru.

Sugiyono. 2008. Metode Penelitian Pendidikan Pendekatan Kuantitaif, Kualitati fdan R\&D, Bandung: Alfabeta.

Suhartini, TEMPO, Kesejahtraan Guru Indonesia, Jakarta, 5 Juni 2007.

Supriadi, Dedi. 1999. Mengangkat Citra dan Martabat Guru. Yogyakarta: Adicita Karya Nusa.

Suprihanto. 2003. Manajemen Stres. Jakarta: RajaGrafindo Persada.

Suryabrata, Sumadi. 1997. Metodelogi Penelitian. Jakarta: Raja Grafindo Persada.

Terry Gregson, Life Without Stres, Jakarta: Prestasi Pustaka Raya, 2007.

Tim Pustaka Merah Putih. 2007. UndangUndang Sistem Pendidikan Nasional, Guru dan Dosen. Yogyakarta: Pustaka Merah Putih. 